\title{
Henry W. Longfellow, Librarian
}

\author{
Dr. Johnson is associate professor of \\ romance languages, University of Oregon.
}

$\mathrm{H}^{2}$ ENRY W. LONGFEllow, poet, scholar, man of letters, read extensively in many fields, and loved books. He was also a college librarian for a period of six years, a fact which has received only minimum treatment from all of his numerous biographers. Sources of information about his librarianship have been lacking or unauthenticated. The importance of his duties as librarian has seemed slight. Yet to a lover of books like Longfellow, to a young man bursting with ambition, to an impressionable, alert scholar, the knowledge gained from six years of experience as librarian was doubtless of greater consequence than has been demonstrated.

It is not the purpose of this article, however, to treat the results of Longfellow's career as librarian, but rather to provide an accurate description of him and his work and to call attention to a curious volume in the Bowdoin College library, which has always been available, I presume, but which has never been used, as far as I know. The volume is entitled $A$ Catalogue of the $\mathrm{Li}$ brary of Bowdoin College in Brunswick, Maine, printed by Joseph Griffin at Brunswick, in $182 \mathrm{I}$, but a copy made specially for the college librarian, with blank pages on which to enter new titles as they were acquired. On the flyleaf in Longfellow's handwriting, is the following statement, indicating that the book had not been used by the librarians who preceded him:

"The Books, whose titles are recorded on the blank leaves of this Catalogue, have

\section{been added to the Library since the College} Year commencing September 1829."

The most recent date of any publication listed in the catalogue is 1842 . Apparently, therefore, the book was the official catalogue of four librarians of Bowdoin, namely Henry W. Longfellow 1829-35, Samuel Adams 1835-36, Henry Boynton Smith 1836-38, and Daniel Raynes Goodwin 1838-53. Adams was tutor of modern languages, Smith was tutor of Greek, and Goodwin was Longfellow's successor as professor of modern languages. Until 19ı6, all the librarians of Bowdoin College were teachers of languages. ${ }^{1}$ It was a natural combination of duties since a great proportion of the titles in the library were in Latin or foreign languages.

Generally, but not consistently throughout the book, there are two printed pages followed by four blanks, making a total of three hundred forty-odd pages. Only the printed pages ( 120 in all) are numbered. The titles are listed under thirty topics arranged alphabetically, beginning with "Agriculture," "Arts," "Astronomy," and ending with "Theology and Sacred Literature," "Voyages and Travels." Seven of the topics appear again in a two-page "Appendix," and the catalogue is concluded with a list of "Books Deposited in the $\mathrm{Li}$ brary by a Friend of the College." The complex structure of the book made errors and changes inevitable. By the time four librarians, or rather, four teachers of lan-

\footnotetext{
1 Information concerning Bowdoin College has been drawn chiefly from two sources: Cleveland, Nehemiah, and Packard, Alpheus Spring. History of Bowdoin College with Biographical Skctches of its Graduates. Boston, 1882 ; Hatch, Louis C. The History of Bowdoin College. Portland, i 927.
} 
guages had used the book for twenty-five years, some of its pages had become overcrowded and untidy. Nevertheless, Longfellow's handwriting, which Poe described as "deliberate and steady," 2 stands out clearly wherever it occurs, and is easily recognizable. Some of Professor Goodwin's characters are similar to Longfellow's in form, but Goodwin's are slanting while Longfellow's are erect. The chance for error in identifying the writer of any title in the catalogue is relatively small.

Bowdoin was a young college, subsisting on meager financial resources in 1829 , when Longfellow went there as its first professor of modern languages and third librarian. The college needed buildings and many other things useful to an institution of higher learning, but it had a good faculty and a collection of books which was a source of genuine pride. "Bibliotheca 8,000 circiter volumina continet" boasts the Catalogus Colegii Bowdoinensis, MDCCCXXVIII, p. i I. President William Allen and six of the professors had been in office when Longfellow was graduated in the Class of I825, yet they were not old men. Parker Cleveland, Professor of Chemistry, was the senior member of the faculty, at forty-nine. The president was forty-five. John Delamater, Professor of the Theory and Practice of Physics, was forty-two, and six other professors were thirty or just beyond. They were good, serious men, educated in New England colleges, mostly Phi Beta Kappas, who dressed habitually in black, and subscribed as far as they were able to President Allen's belief that discipline lies at the basis of all true religion. During Allen's term in office, maintaining discipline ranked next in importance to religion. Teaching came third. $^{3}$

2 The Complete Works of Edgar Allan Poe, ed., by James A. Harrison. I 7 vols. New York, I902, XV:I92 ${ }^{3}$ See Smyth, Egbert C. Three Discourses upon the
ames A. Harrison. I vols. New York, I902, XVirg.
Professor Longfellow, the tenth member of the faculty, was only twenty-two, but with three years of post-graduate study and travel in Europe to look back upon, he was a man of the world compared with his colleagues. He looked about, and with the aplomb of a Parisian snob wrote to a friend : "I lead the life of an anchorite; to be sure I have many acquaintances-mais elles en sont pas $d u$ bois dont on fait les amis." His ideas on discipline and dress were different too. "You can judge what a poor disciplinarian he must be" wrote Ebenezer Everett, a Bowdoin trustee, in a letter recommending Longfellow to Simon Greenleaf of Harvard, "when you find that he keeps himself on such easy, friendly terms with the students, that discipline has nothing to do in the connection." fessor Longfellow's clothes, flashing colors inspired by the romantic dandies of Europe, made him a delight to the eyes of the young ladies and the object of many a gibe from men, particularly the older men. Edward Everett, somberly dressed, rose to address the Phi Beta Kappa Society of Harvard in I833 after Longfellow had read a poem prepared for the occasion. "I find myself but a follower in a field where the flashing sickle has already passed," said Everett. "Some of the young ladies of Cambridge remembered this," says Samuel Longfellow, Henry's brother and biographer, "and when the young professor afterward came to Harvard they called him 'the Flashing Sickle." Samuel Longfellow interprets Everett's remark as a comment on Longfellow's poem. ${ }^{6}$ It applies equally well if not better to young Professor Longfellow's appearance.

Religions IIistory of Bowdoin College. Brunswick, I 858 . 1. 39 . now at the Longfellow House in Cambridge, Mass.

5 See Johnson, Carl L. Professor Longfellow of Har. vard. Fugene, Ore., I944. p. 6.

6 See Longfellow, Samuel. Iife of Henry Wadszorth Longfellow. 3 vols. Boston, i891. I: i95. 
The library was housed on the second floor of the chapel building, an unattractive wooden structure which had been built in I 805 at a cost of $\$ 800$. The librarian, at a salary of $\$ 100$ per year, had the responsibilities of an entire library staff of today. He ordered books, cataloged them, charged them out to students and faculty, and jogged the memory of borrowers when books were overdue. But despite his numerous responsibilities, his duties were not burdensome. The library was open only from noon to one o'clock. With the funds available, only a limited number of books could be purchased each year. Cataloging them involved merely entering the titles in the librarian's catalog described above, and finding a suitable shelf for the new volume or volumes. A system of call numbers had not yet been adopted. From the librarian's catalog, it appears that the numbering of books in the Bowdoin College Library was first done by Daniel Raynes Goodwin. Each title which he entered in the catalog is set toward the right, leaving a margin on the left for writing in the call number. Longfellow left no such spaces, except by chance.

The old Bowdoin library was simply a repository for books, not planned or equipped as a place of study. How many books were charged out by Librarian Longfellow in a week or a term cannot be known exactly, but probably the number was small. Practically every student there belonged to a literary society, each of which possessed a good collection of books. Students went to the college library only to get the more learned, highly specialized works. For lighter, pleasurable reading, they patronized the Peucinian or Athenaean society. The Visiting Committee of I 828 stated that they believed that "the society libraries were of more value to the student than was the college library."
Longfellow was not yet a celebrity or even a poet when he served as librarian at Bowdoin. He had written some undergraduate verse, but he was not elected poet of his college graduating class. When he went abroad in 1826 to study foreign languages, he stopped writing poetry. His first successful poem was $A$ Psalm of Life, written in 1838 , after he had resigned from Bowdoin, spent another year abroad in order further to prepare himself for a professorship in foreign languages at Harvard, and occupied for two years the chair left vacant by the resignation of George Ticknor. Longfellow stood high as a teacher and scholar before achieving any fame as a poet. While performing his duties as librarian, he did not sit idly by his desk, waiting for time to pass. Cyrus Hamlin, a Bowdoin graduate in the class of I 834, described Longfellow, the librarian, as follows:

As freshmen, we saw him only in the library. He was always apparently pursuing some investigation or absorbed in some book: and yet nothing escaped his attention. The assistants were kept up to the mark, and no irregularity was allowed. He attended readily to any question about book or subject, and then resumed his reading; and always seemed so absorbed and yet attentive that he seemed to have two personalities. ${ }^{7}$

The list of books which the Bowdoin library acquired while Longfellow was its librarian includes 274 titles (roughly 700 volumes) ranging in magnitude from a single page to forty volumes. Only twentyeight of these titles are not included in the Catalogue of the Books in the Bowdoin College Library, published in 1863 . Viewed in its entirety, the list reflects the utilitarian character of Bowdoin thirty years after its founding, with its interest chiefly in theology, the ancient languages,

\footnotetext{
${ }^{7}$ Quoted from Samuel Longfellow, op. cit., I, I 83.
} 
history, and the sciences. In the printed catalogue of $182 \mathrm{I}$, the titles under Belles Lettres take up only two pages, and include nothing of Shakespeare, Pope, or Dryden and only the prose writings of Milton. Partly because of the activity of the two literary societies the Bowdoin library had spent little for books of a purely literary character. The officers of the college generally had manifested a decided preference for useful, informative books. Professor Longfellow was thoroughly aware of this fact. He gave to the library copies of five of the six foreign language textbooks which he edited, ${ }^{8}$ but he chose not to give Bowdoin a copy of his Outre-Mer, the literary account of his first trip to Europe, written in imitation of Irving's Sketch-Book, and published in two parts, I833, I834. To Harvard University on the other hand, he sent a nicely autographed copy of OutreMer, now in the Houghton Collection. Notwithstanding Bowdoin's predilection for books of practical knowledge, the college library acquired, during Longfellow's tenure and doubtless at his behest, several important literary works, including Dante's Divina Commedia, the collected works of Goethe in forty volumes, the complete works of Chateaubriand in twenty volumes, the plays of Racine, six of the works of Washington Irving, and the poetry of Milton. ${ }^{9}$

Many of the authors of the new books

${ }^{8}$ Norclas Españolas. Brunswick, I831; Saggi de No. vellieri Italiani d'Ogni Secolo. Boston, 1832; Manuel de Proverbes dramatiques. Portland, 1830 ; Elements of French Grammar by Charles Lhomond, 2d ed. Boston, I 831 ; Coplas, by Jorge Manrique, translated by Longfellow. Boston, 1833 .

9 Dr. Lawrence Thompson asserts that because of Longfellow's growing interest in German while he was at Bowdoin, "he added many volumes by German authors Bowdoin, "he added many volumes by German authors
to the inadequate Bowdoin Library-the works of Klop. stock, Gellert, Goethe, Herder, and Korner, good editions of the Nibclungcnlicd and Heldcnbuch, together with several collections in the fields of literature, history, and language." See Young Longfellow. New York, I93 p. I $7 \mathrm{I}$. The list shows only the works of Goethe to support Thompson's statement.

James Taft Hatfield claims that Longfellow added to his private collection the authors and works listed by his private collection the authors and works listed by
Thompson. See Nero Light on Longfellow. Boston, I 933, P. 25. acquired were men whom Longfellow had met or heard of on his first trip to Europe I826-1829. Before embarking at New York he got the advice of George Bancroft who had studied abroad. It was, no doubt, with a feeling of friendship that he ordered Bancroft's first volume of the History of the United States from the Discovery of the American Continent to the Present Time, printed at Boston, I834. Abel François Villemain was the most stimulating lecturer at the Sorbonne during Longfellow's stay in Paris from June 1826 to February 1827. When the three volumes of his Cours de littérature française came out in $1828-29$, Librarian Longfellow was able to read chapters which he had heard delivered orally in the classrooms of the University of Paris. François Guizot, historian, and Victor Cousin, philosopher, were eminent professors in their fields also, but they had been removed from their chairs at the Sorbonne because of their opposition to the reactionary Restoration government. Along with Benjamin Constant, the most eloquent leader of the liberals, they were, however, among the most talked-of men in France. ${ }^{10}$ In the faculty discussions, which preceded the selection of books to be ordered for the Bowdoin library, Professor Longfellow could if necessary give personal data on all these living writers and many others in order to strengthen his recommendation of their works. Obadiah Rich was the American consul at Madrid while Longfellow was there. Washington Irving had rooms in Rich's house, and frequently of an evening a small group of Americans, including young Longfellow, gathered there to enjoy the hospitality of their host and at the same time to bask in the presence of

\footnotetext{
${ }^{10}$ Guizot. Cours d'histoire moderne. \& vols. Paris, I 820-30; Cousin. Fragments philosophiques. Paris, I 826, Nouveaux fragments philosophiques. Paris, I 828 and Cours de l'histoire de la philosophic. Paris, I 820 and Conirs de listoire de la phibsophie. Paris, 1829 Constant. De la religion considerec dans sa source, ses
formes et ses dizeloppements. $2 \mathrm{~d}$ ed. 5 vols. Paris, formes ct
} 
their greatest native writer. Even without the spur of friendship, Longfellow would probably have ordered six titles from the writings of Irving, namely The Alhambra, Bracebridge Hall, the Conquest of Granada, The Sketch Book, Tales of a Traveller, and History of the Life and Voyages of Christopher Columbus. It was presumably largely out of gratitude that he entered in the Bowdoin catalogue a title by Obadiah Rich, printed in London, I 832, A Catalog of Books, relating principally to America. In Germany, Longfellow had studied for several months at the University of Göttingen, and had sat in the classes of Arnold Hermann Ludwig Heeren, professor of history. At Göttingen also, Longfellow had become acquainted with the name and the writings of Karl Otfried Müller, professor of ancient literature. Three titles by Heeren and one by Müller were added to the Bowdoin collection. ${ }^{11}$ When he sailed for Europe, Longfellow had taken with him a letter of introduction from Ticknor to Robert Southey. He did not succeed in using the letter but on becoming librarian he ordered Southey's Chronicle of the Cid, translated from the Spanish, Amadis of Gaul and Palmerin of England translated from Portuguese and Sir Thomas More, or Colloquies on the Progress and Prospects of Society.

Not one of the books acquired by the Bowdoin College Library during Longfellow's librarianship was by a Bowdoin author, excepting the five textbooks in foreign languages by Longfellow himself. Several of the authors were at Harvard, however, where Longfellow went as head of the department of foreign languages in

11 Heeren. Historical Researches into the Politics, Intercourse, and Trade of the Carthaginians, Ethiopians, and Egyptians. 2 vols. Oxford, I 833; Historical $R e$ scarches into the Politics, Intercourse, and Trade of the Principal Nations of Antiquity. 3 vols. Oxford, I833; A Manual of the History of the Political System of EuA Manual of the History of the Political System of Eu-
rope and Its Colonies. 2 vols. I 834 ; Muller. The Hisrope and Its Colonies. 2 vols. I 834 ; Muller. The His-
tory and Antiquities of the Doric Race. 2 vols. Oxford, 1830 .
1836. Francis Sales, instructor in Spanish, and Pietro Bachi, instructor in Italian, retained their positions and served under Longfellow. ${ }^{12}$ Three other authors, Josiah Quincy, Jared Sparks, and Edward Everett became presidents of Harvard and Longfellow served under them. Joseph Story and Simon Greenleaf made up the faculty of the Harvard Law School. The name Benjamin Peirce was on Harvard's roster in 1836 as professor of astronomy and mathematics, but it was his father who had compiled the catalog of the Harvard Library and left the history of the university, published posthumously in I833. Perhaps without being librarian Longfellow would have known these authors and titles, but as librarian, knowing authors and books was an inescapable part of his work. When he left Bowdoin, he already knew personally or through their writings half of the faculty of Harvard.

Other titles and authors in the list invite comment also, for example the name of Henry Schoolcraft, since it marks Longfellow's first acquaintance with the author whose works provided much of the subject matter of Hiawatha. "My poetry is written seldom," Longfellow once remarked to a friend, "the Muse being to me a chaste wife, not a Messalina to be debauched in the public street."13 $\mathrm{His}$ interest in the American Indian was first manifested in a college debate in the year 1823 , and intensified by the writings of Schoolcraft which began to appear in 1834 , but Hiawatha was begun only in 1854 . The Catalogue of the Books in the Bowdoin College Library contains abundant evidence that Longfellow's experience as librarian, in his twenties, was one of the formative influences in his life.

12 Bachi, A Grammar of the Italian Language. Boston, I 829 ; Scclta di Prose Italiane. Cambridge, I 828 ; Sales, Scleccion de Obras Maestras Dramaticas. Boston, 828 . 13 "Longfellow's Letters to Samuel Ward,"Putnam's Monthly Magazine, October I907, p. 4I. 